بررسى بيان زنهاى Hv TIP2;3 و Hv TIP4;1 در زنوتيبٍ هاى حساس و متحمل

جو تحت تنش شورى

\author{
رباب سلامى اء"، سيد ابو القاسم محمدى'، سارا غفاريان`و محمد مقدم \\ 1 - دانش آموخته كارشناسى ارشد، كروه بهنزادى و بيوتكنولوزى كشاورزى، دانشكده كشاورزى، دانشخاه تبريز، تبريز

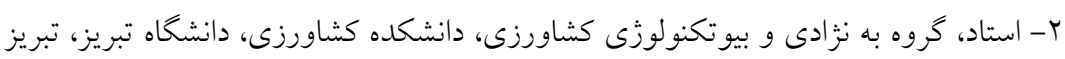

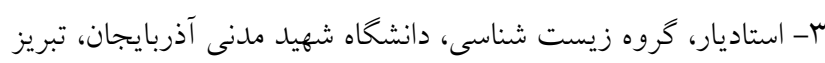

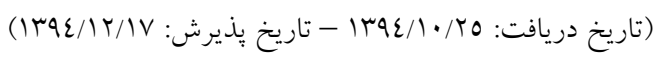

جكيده

جو متحمل ترين غله در بين غلات نسبت به تنش شورى است و در گستره وسيعى از شرايط آب و هوايى كشت مىشود. براى

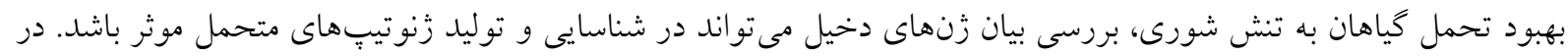

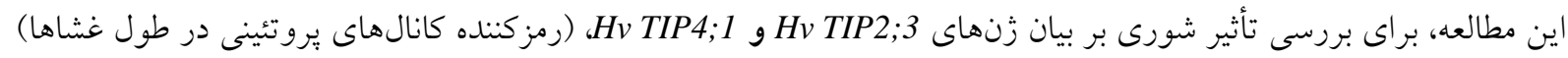

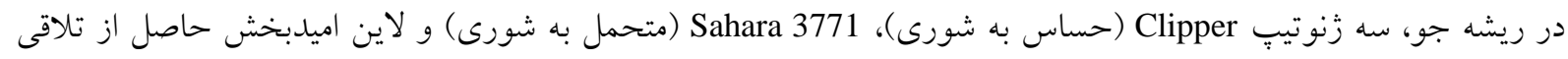

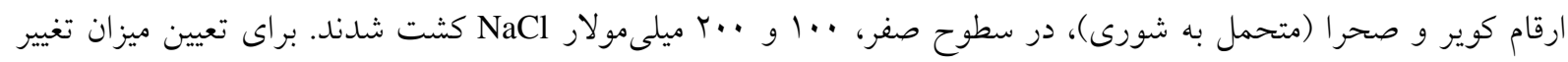

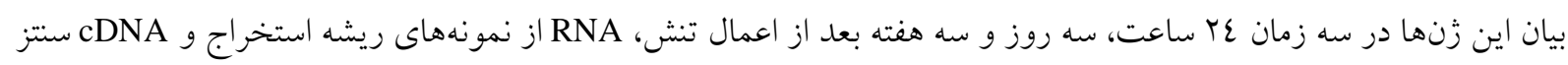

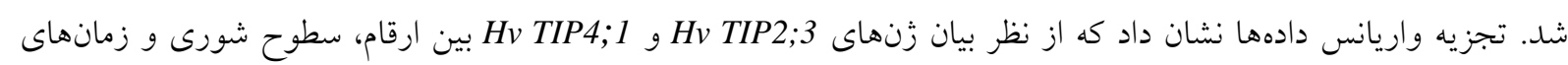

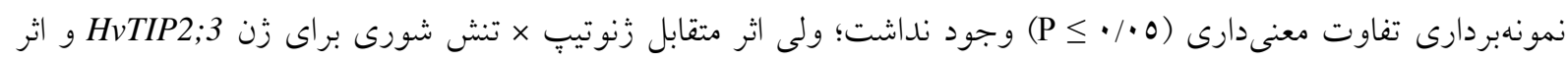
متقابل زنوتيبٍ × زمان نمونهبردارى براى هر دو زن مورد مطالعه تفاوت معنى دار ( P

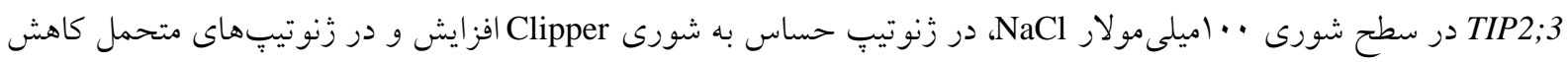

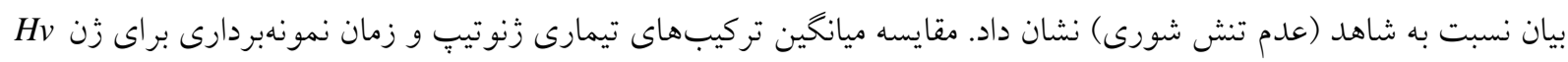

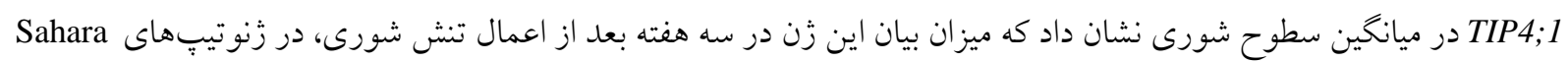

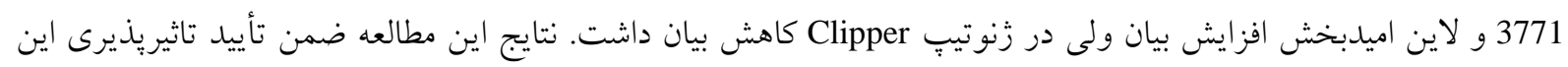

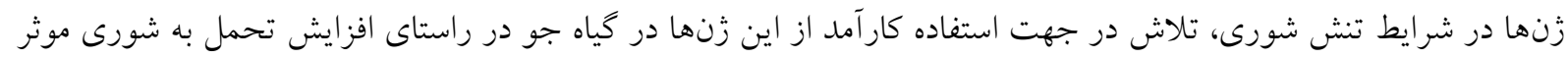

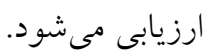

واز كان كليدى: آكويورين ها، الكوى بيان، يروتئينهاى درونى تونويلاست، جو، زنهاى HV TIP2;3 و HIP4;1 
شورى باعث اختلالات فيزيولوزيكى و متابوليكى در

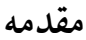
كياهان شده و رشد و نمو، عملكرد و كيفيت محصول را تحت تاثير قرار مىدهد (Knight and Knight, 2001). تحمل به شورى يك ويثز گى تركيبى متشكل از سازوكارهاى مختلف است كه تعيين كننده توانايى كياه براى بقا در شرايط تنش شورى و تكميل تجرخههاى رويشى و زايشى

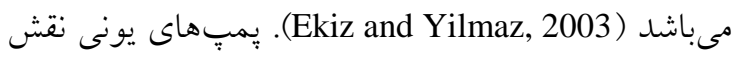
برجستهاى در تجمع نمك در واكوئلها به عهله دارند. در واقع تفاوت در قابليت نسبى گياهان براى انتقال و جابجايى يونها از غشاهاى سلولى به ويزه غشاى واكوئلها اساس اختلاف گياهان در تحمل به شورى را تشكيل مىدهد. در واقع گياهان متحمل به شورى، از خسارت تنش شورى به واسطه بيرون راندن يونها از برگها و يا تجمع يونها در واكوئلها و دور نكه داشتن آنها از سيستم سوخت و ساز سلولى، از تأثيرات سوء شورى در امان مى مانند ( Shannon .(et al., 1985 تحمل بالاى جو در مقابل تنش شورى به تجمع $\mathrm{Na}^{+}$ واكوئلهاى درون سلولى و ساخت محلولهاى سازگار جهت تنظيم بتانسيل اسمزى در سيتويلاسم مربوط مى شود (Widodo et al., 2009) Hassine et al., 2008; Yousif et al., ) رشد گياه مىشود 2010). عقيده بر اين است كه تراوايى غشاهاى سلولى ريشه جو نسبت به يتاسيم بيش از سه برابر سديم مىباشد

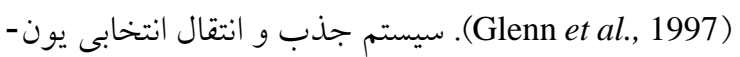
ها توسط كانالهاى غشا در غلات به علت دارا بودن كارايى مطلوب در تبادل سديم موجب شده است كه كاهى غلات به دليل داشتن اين ويزگ گى در زمره گونههاى متحمل به شورى گروهبندى شوند (Poustini, 2000). سازگارى به تنش شورى ويزگ گیى بيجيدهاى است كه با تغيير بيان مولكولى، مانند فر آيندهاى فيزيولوزيكى، طى تكامل كياه كنترل مىشود (Sadder et al., 2013 ( مطالعات نشان داده كه زنهاى متعدد در ياسخ به شورى دخالت دارند (Gao et al., 2013). كزارش شده است كه تنشهاى غيرزيستى از جمله شورى از طريق تغيير در بيان بروتئينها،

جو يس از كُندم، برنج و ذرت جهارمين غله مهم دنيا است

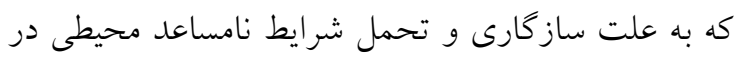

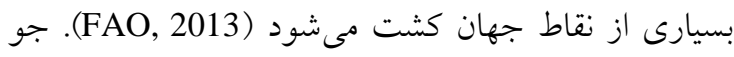

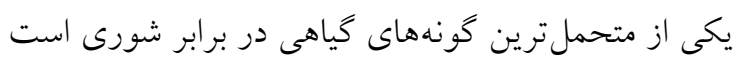
(Jiang et al., 2006) در برنامهاى تناوبى قرار مى گيرد.

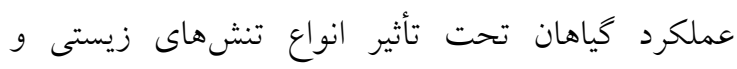

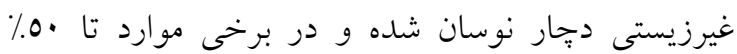

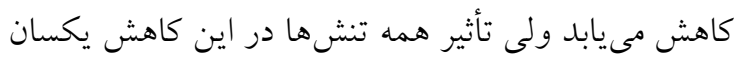

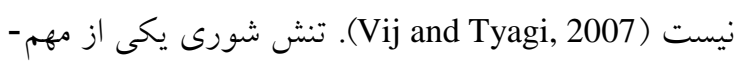
ترين تنشهاى غيرزيستى مىباشد كه سطح وسيعى از

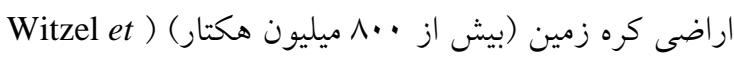
1. al., 2009

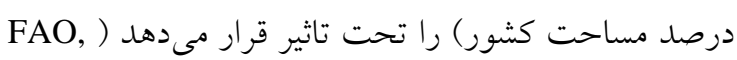

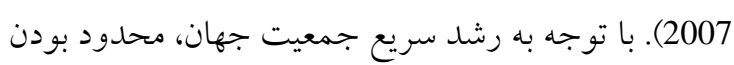

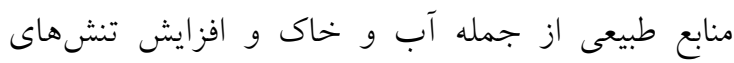
زيستى و غيرزيستى، توليد گياهان متحمل به انواع تنشهاب إنها

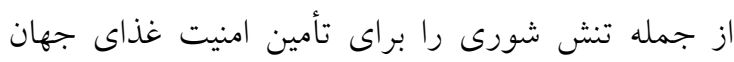
ضرورى ساخته است (Witzel et al., 2009). شورى باعث ايجاد تنش اسمزى و تنش يونى مى شود. تنش

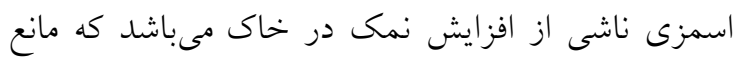

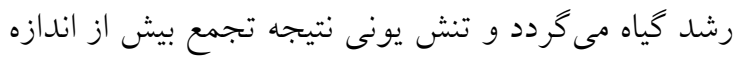

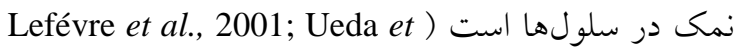
al., 2003 اين امر كاهش جذب آب از خاك به خصوص در مناطق خشك و نيمه خشك را به دنبال دارد، در نتيجه سرعت طويل شدن سلولها و تورزسانس كاهش يافته و

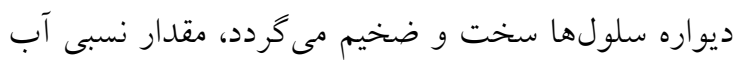

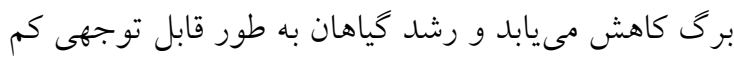

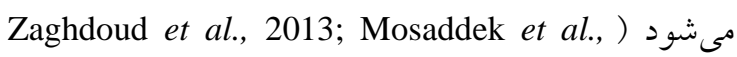

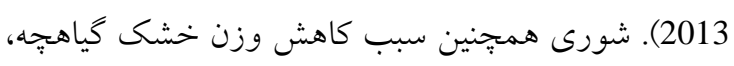
غلظت CO $\mathrm{CO}_{2}$ داخلى، كارئيى دريافت نور توسط فتوسيستم

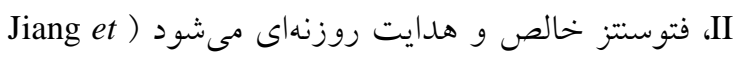
.al., 2006 


\section{تنش شورى بود. \\ مواد و روشها}

مواد گياهى: مواد گياهى مورد استفاده شامل ارقام جو روت Clipper Sahara 3771

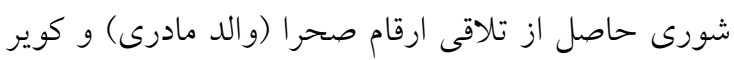

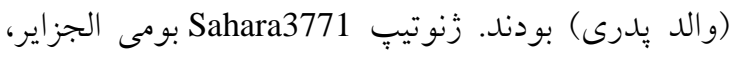
زمستانه، شش رديفه، يابلند و متحمل به شورى و زَنوتيبٍ

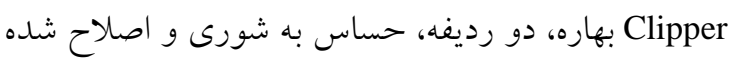

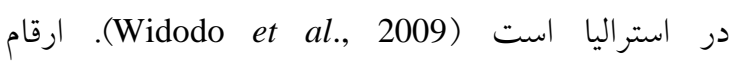
Sahara3771 و و Clipper از دانشخاه استر الياى غربى و لاين متحمل به شورى از موسسه تحقيقات اصلاح و تهيه نهال

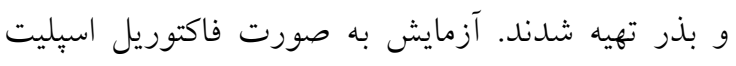

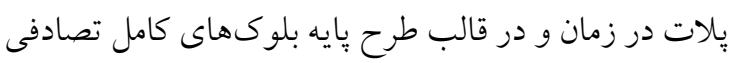

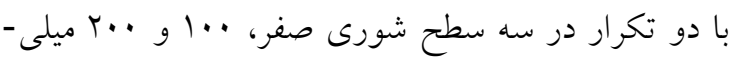

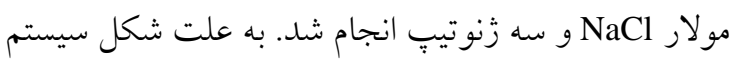

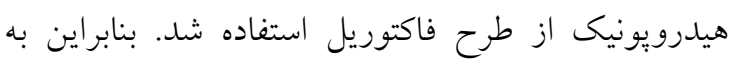
خاطر تكرار بيشتر، فاكتورهاى فرعى (زمان نمونه بردارى)

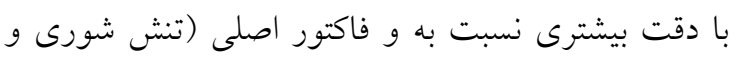

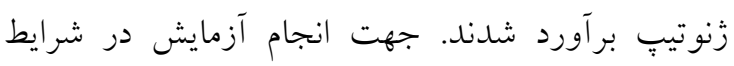

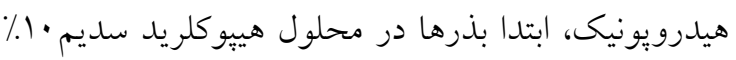

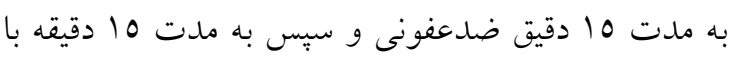

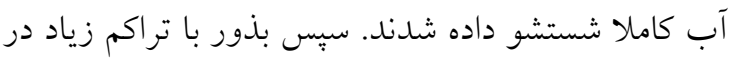
سنكريزههاى سيستم هيدرويونيك كشت شدند. روى لوله -

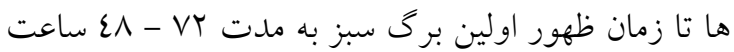

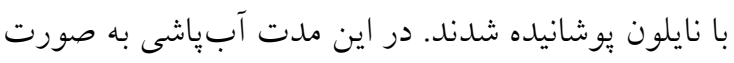

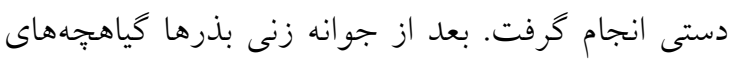

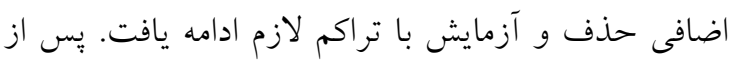

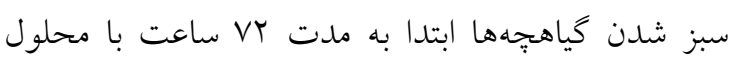

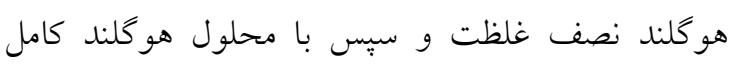

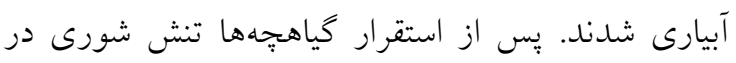
مرحله سه بركجهاى اعمال شد. به اين ترتيب كه ابتدا كياهجْهها به مدت ع r ساعت تحت تنش شورى •0 ميلى مولار، سبّ

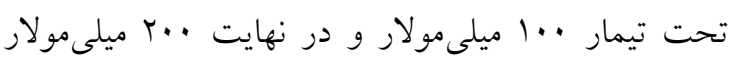

هدايت آبى را كاهش مى دهند (Tyerman et al.,2002). تحقيقات نشان داده است كه تنشهاى غيرزيستى از جمله

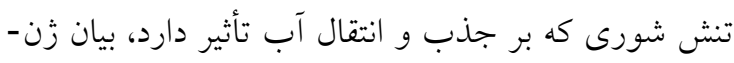

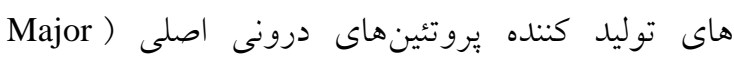

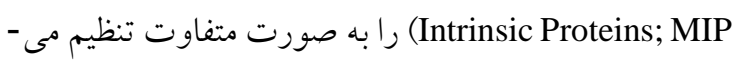

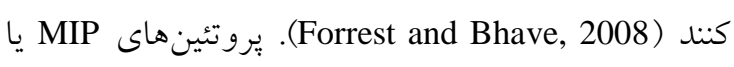

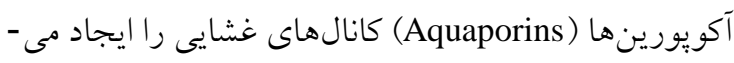
كنند كه باعث تسهيل انتقال آب و مولكولهاى كورئه

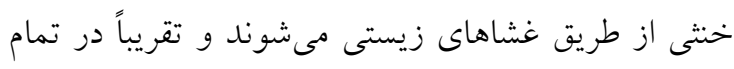

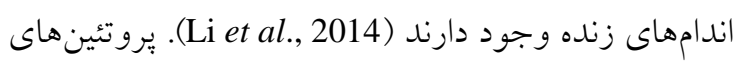
در جو شامل ينج يروتئين درونى تونويلاستى دونى و Hv TIP2;3 ،HvTIP2;2 ،HvTIP2;1 ،Hv TIP1;1) NOD26 (HvNIP2;1) يك يروتئين مشابه و (HvTIP4;1 يروتئين غشاى پِاسمايى (Hv PIP2;1) هستند ( (et al., 2011

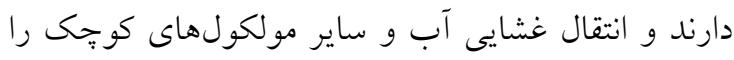

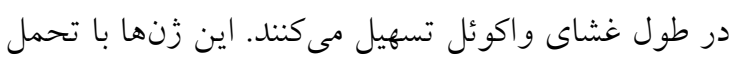

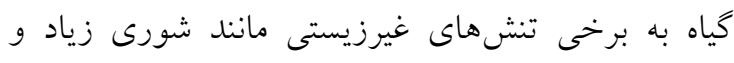
خشكى كه باعث كمبود آب مىشوند نيز در ارتباط مى باشند (Wang et al., 2011)

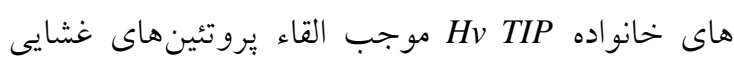

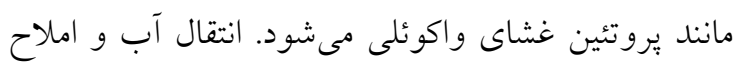

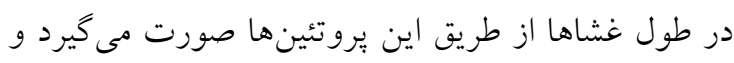

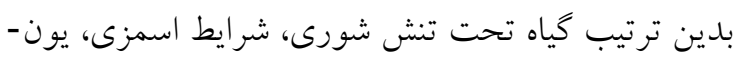

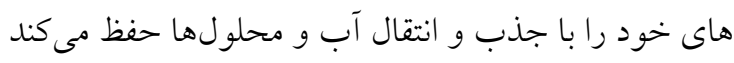

.(Ligaba et al., 2011) يكى از اثرهاى تنش شورى القاى تنش اسمزى به كياه و

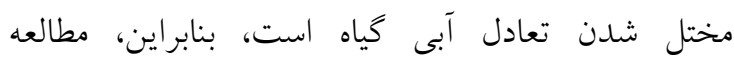

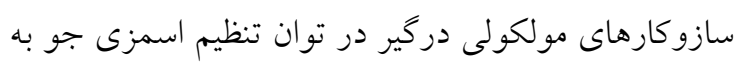

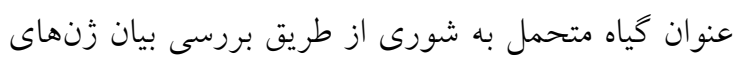

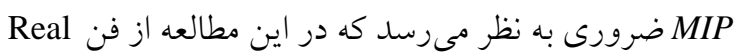

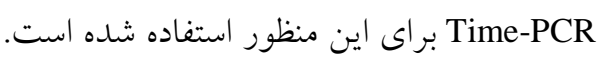
از اين رو هدف اين مطالعه، ارزيابى ميزان بيان دو زن از مان زنهاى خانواده Hv TIP در ريشه زنوتيبٍهاى جو تحت 
PCR براى زن هدف (شورى) و زن مرجع (a-Tubulin)،

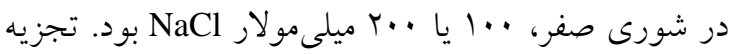
واريانس دادههاى تغيير بيان زنها، براساس مدل مدرى آمارى

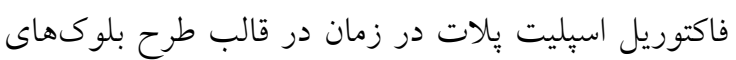
كامل تصادفى توسط نرم افزار SAS انجام شد. قبل از تجزيه

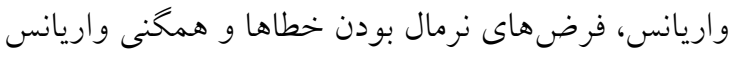
خطاها مورد بررسى قرار گرفت. نتايج و بحث بيان زنهاى ياسخ دهنده به شورى: بررسى منحنى هاى

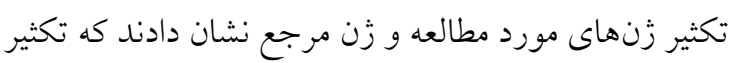
به خوبى و با عملكرد مناسب صورت گرفته است و روند موند

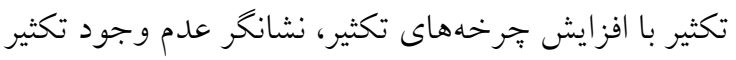

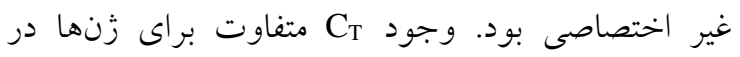
تيمارهاى مختلف شورى بيانكر وجود تفاوت در بيان زن هاى مورد مطالعه در سطوح مختلف شورى است. منحنى ذوب زن مرجع مو مو زنهاى مورد مطالعه

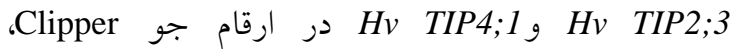
Sahara3771 و لاين اميدبخش تحت تنش شورى صفر،

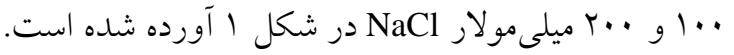
كفتنى است كه در مقالات مختلف قابليت زنtubulin به عنوان زن مرجع، جهت آناليز بيان زن ثابت شده است (et al., 2011; Gimeno et al., 2015 and Llanos et al., (2015; Wan, است وجود فقط يك نقطه اوج بالاتر از آستانه براى زن

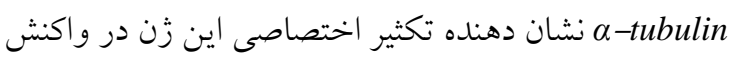
زنجيرهاى بلىمراز است. براى زنهاى Hv TIP2;3 و HotIP4;1 اختصاصى زن، يكى نقطه اوج كوجى نيز مشاهده شد. شايان ذكر است كه وجود نقطه اوج كوجى علاوه بر نقطه اوج اصلى نمى تو اند اريبى در بر آورد ميزان غلظت زن هدف ايجاد كند (QIAGEN, 2005).
قرار گر فتند، در مطالعات متعدد مشاهده شده است كه طى روزهاى مختلف پِ از اعمال تنش بيان زن تغيير

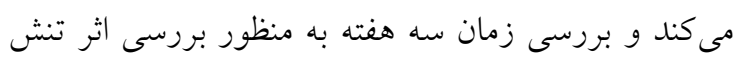

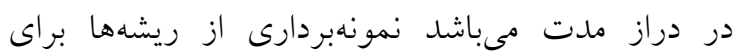

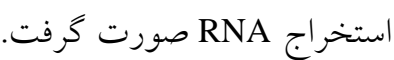
واكنش زنجيرهاى پليمراز در زمان (Real Time-PCR): استخراج RNA از نمونهاى ريشه با استفاده از كيت استخراج RNX_PLUS (شركت سينازن) انجام شد. جهت حذف آلودگىهاى احتمالى DNA، نمونههاى RNA استخراج شده با آنزيم DNase تيمار و كميت و كيفيت نمونههاى RNA به ترتيب توسط اسيكتروفتومتر و

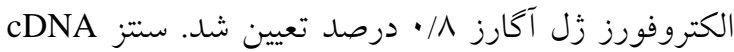
(در حجم . • ميكروليتر) بر اساس دستورالعمل كيت Thermo Scientific RevertAid First Strand cDNA در دو زمان انجام گرديد.cDNA Synthesis Kit حاصل به عنوان الحو جهت تكثير زنهاى Hv TIP2;3 و

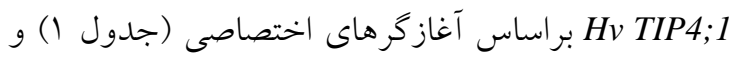
تكنيك Real Time-PCR با رنغ آميزى SYBR Green استفاده شد. واكنش Real Time-PCR با استفاده از كيت TAKARA در حجم •( ميكروليتر انجام گرفت (جدول Y).

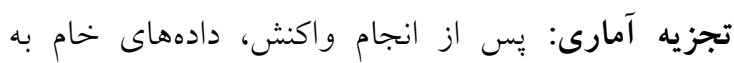
صورت (Threshold cycle) Ct از دستخاه استخراج شد. Livak دادهاى خام حاصل با استفاده از فرمول بيشنهادى (2001) and Schmittgen $C \mathrm{~T}=(C \mathrm{~T}$ Target $-C \mathrm{~T} \alpha-$ tubulin $)$ salinity $\mathrm{x}-(C \mathrm{~T}$ Target $-C \mathrm{~T} \alpha-$ tubulin) salinity 0 $2^{-\Delta \Delta}$

با بررسى منابع متعدد اين روش به عنوان روش تصحيح

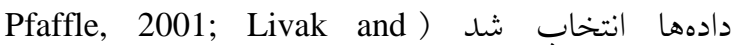
Schmittgen, 2001;Zhu et al., 2005; Besse et al., 2011 $C_{\mathrm{T}} C_{\text {TTarget }}$ (and Knipfer et al., 2011 Real Time- a-tubulin 
جدول ا- توالى آغاز گرهاى اختصاصى زنهاى Hv TIP4; 1 و TIP2;3

Table 1. Sequence of specific primers for $H v$ TIP2;3 and $H v$ TIP4;1 genes

\begin{tabular}{|c|c|c|}
\hline \multicolumn{2}{|c|}{ آغازكر (Primer) } & \multirow{3}{*}{$\begin{array}{c}\text { زن } \\
\text { Gene }\end{array}$} \\
\hline رفت ('-3'-5) & برگشت ('-5'-5) & \\
\hline Forward $\left(5^{\prime}-3^{\prime}\right)$ & Reverse $\left(3^{\prime}-5^{\prime}\right)$ & \\
\hline CTACTGGGTTGCGCAGCTC & GTGCCGAGGGATCCCTTC & $H v T I P 2 ; 3$ \\
\hline CACCGACAATAAGGCCGGT & CGGTGCTGTACGTGGTGG & Hv TIP4; \\
\hline AGTGTCCTGTCCACCCACTC & AGCATGAAGTGGATCCTTGG & $\alpha$-tubulin \\
\hline
\end{tabular}

جدول r- تركيب محلول واكنش Real Time-PCR

Table 2. Components of Real Time-PCR reaction

\begin{tabular}{|c|c|}
\hline 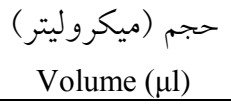 & $\begin{array}{c}\text { مواد } \\
\text { Materials }\end{array}$ \\
\hline \multirow{3}{*}{$0.75+0.75$} & مخلوط واكنش SYBR Green \\
\hline & SYBR Green PCR master mix \\
\hline & آغازگر يِشرو و يس رو (0 ميكرومولار) \\
\hline 1 & $\begin{array}{c}\text { Forward and reversed primer }(5 \mu .1) \\
\text { cDNA }(\mu .1)\end{array}$ \\
\hline 5 & آب مقطر استريل \\
\hline
\end{tabular}

با تأثير بر جذب و انتقال آب داراى اثر متمايز بر بيان زن هاى MIP از جمله زنهاى TIP مى TIاشد ( Forrest and Bhave, 2008 (B). كزارش شده است كه بروتئينهاى TIP كه در طول غشاى واكوئل قرار دارند با تحمل گياه به شورى در ارتباط هستند (Wang et al., 2011). ميزان بيان زن هاىTIP در ارقام مختلف گياهى و نيز اندامهاى گياهى مختلف متفاوت است ( Therman et al., 2002; Zhao (andLigaba et al., 2011; Gao et al., 2013 بيان زنهاى MIP در برنج طى مراحل مختلف رشدى و در بافتهاى مختلف كزارش شد كه بيان اين زنها در بافتها Sakurai et al., ) ور مراحل مختلف رشدى، متفاوت است 2005). همجنين با مطالعه جِندين زن پِاسخ دهنده به شورى در جو مشاهده شد كه r9 زن تحت تنش شورى تغيير بيان نشان مىدهند (Ueda et al., 2004). مطالعات نشان داده است كه رونوشت همه زنهاى MIP، در ريشه جو فراوانتر از اندامهاى هوايى است وHv TIP2;3 بيشترين و Hv
تجزيه واريانس بيان زنهاى Hv TIP2;3 و Hv TIP4;1

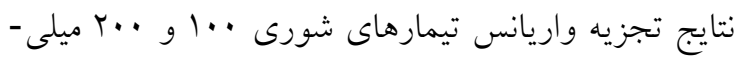
مولار NaCl و شاهد بر بيان زنهاى Hv TIP2;3 و HvTIP4;1 اميدبخش در سه زمان ع r ساعت، سه روز و سه هفته بعد از اعمال تنش به صورت فاكتوريل اسِليت بِلات در زمان در قالب طرح يايه بلوكهاى كامل تصادفى براساس داده-

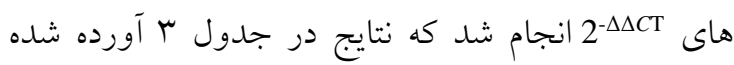
است. بين تكرارها، ارقام، سطوح مختلف شورى و زمانهاى مختلف نمونهبردارى از نظر تغيير بيان هر دو زن مورد بررسى، تفاوت معنى دار وجود نداشت. اثر متقابل زنوتيبٍ × تنش شورى براى زن HvTIP2;3، و اثر متقابل دو جانبه زنوتيّ × زمان نمونهبردارى براى هر دو زن مورد مطالعه

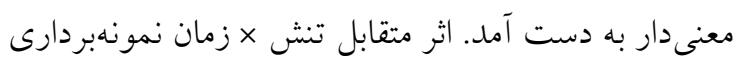
و اثر سهجانبه زنوتيبٍ × تنش شورى × زمان نمونهبردارى نيز براى زنهاى مورد مطالعه معنى دار نبود. تنش شورى كه 
شورى Sahara3771 و لاين اميد بخش به طور معنى دار افزايش يافت و بيشترين بيان مربوط به لاين اميد بخش بود. ميزان تغيير بيان زن Hv TIP2;3 در سه زنوتيبٍ در سطح شورى ".اميلى مولار NaCl نشان دهنده پِاسخ مشابه زَنوتيِّهاى متحمل به شورى در مقايسه با زنوتيبٍ حساس به شورى Clipper بوده و در زنوتيبٍ هاى متحمل كاهش بيان نسبت به شاهد مشاهده شد. در حالى كه در سطح

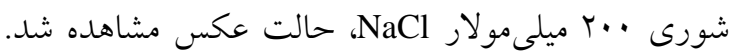
بنابراين، مىتوان نتيجه گرفت كه كاهش بيان زن HV TIP2;3 در زنوتيبٍ هاى متحمل يك نوع سازوكار تحمل

$$
\text { در برابر شورى ملايم است. }
$$

كمترين تعداد رونوشت را در جو دارند

.(Ligabaet al., 2011)

تغييربيان زن HV TIP2;3 در ارقام Clipper، Sahara3771 و لاين اميد بخش در تيمارهاى شورى +.1 و .. ميلى مولار NaCl در مقايسه با شاهد (صفر ميلىمولار (NaCl

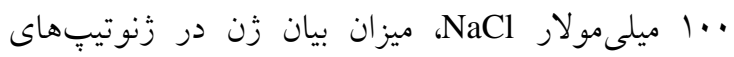
متحمل به شورى Sahara3771 و لاين اميد بخش به طور معنى دار كمتر از زنوتيب حساس به شورى Clipper بود. در عين حال در تيمار شورى ·. . ميلى مولار NaCl Nيز ميزان بيان زن Hv TIP2;3 در زنوتيب حساس به شورى Clipper به طور معنى دار كاهش ولى در زنوتيٍِهاى متحمل به

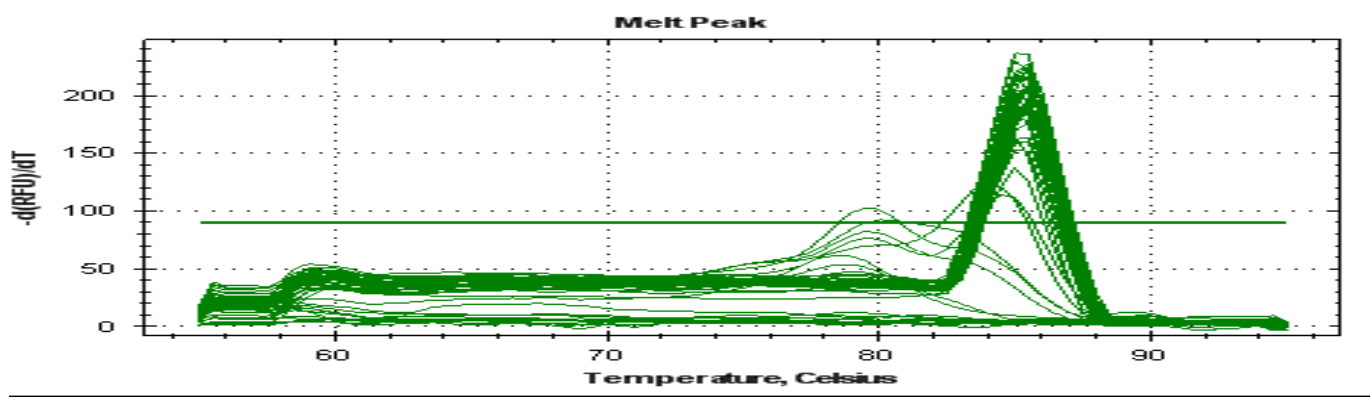

(A)

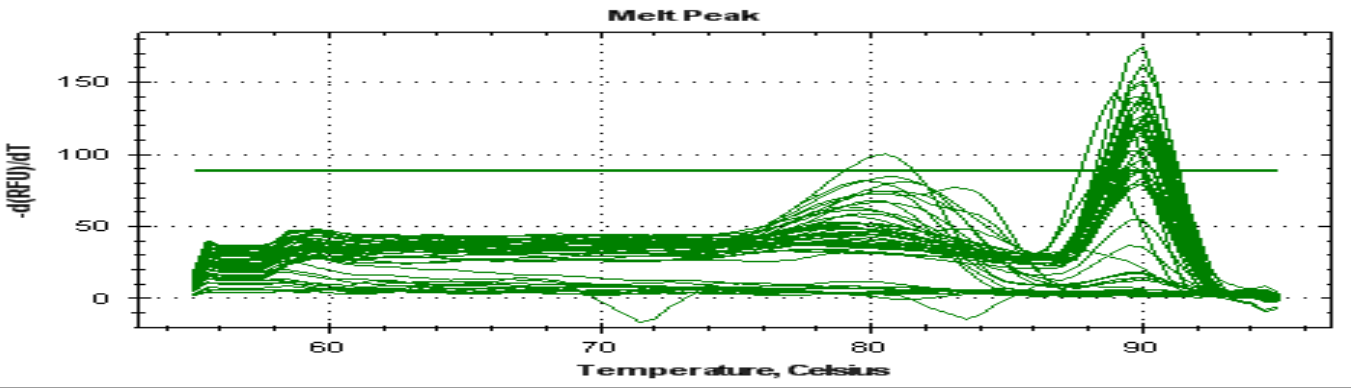

(B)

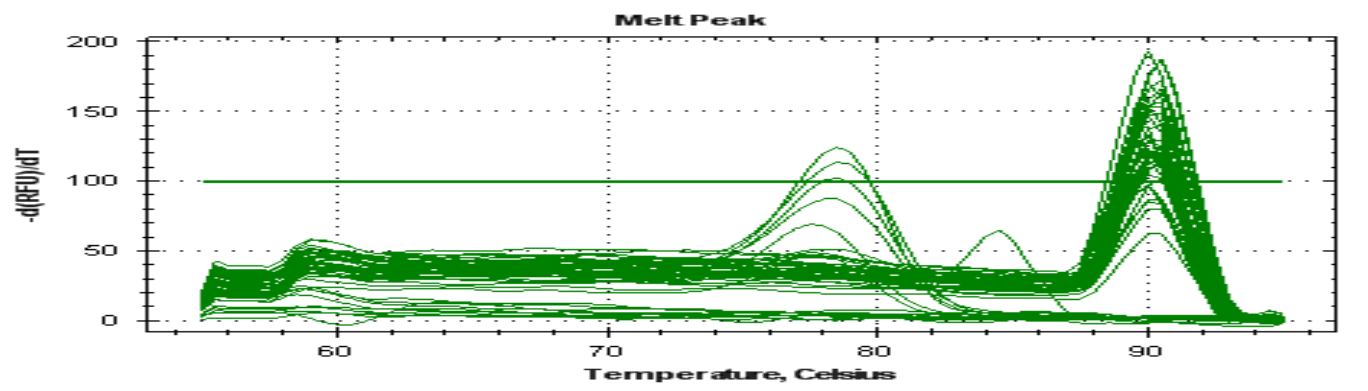

(C)

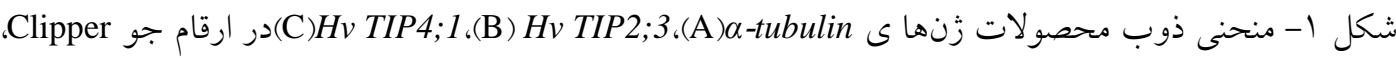

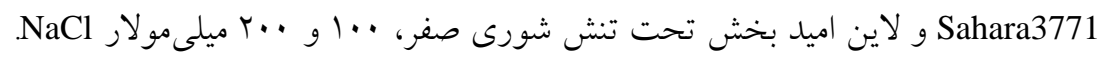

Figure 1. The melting curve. A: $\alpha$ - tubulin; B: Hv TIP2;3; C: Hv TIP4;1 genes in barley genotypes under salinity levels of 0,100 and $200 \mathrm{mM} \mathrm{NaCl}$ 
يُوهشهاى رنتيك گياهى / جلد Y / شماره Y

ميلى مولار NaCl به مدت عات ساعت نسبت به

Besseet al., 2011; ) شرايط فاقد تنش مشاهده شد

.(Ligabaet al., 2011
Hv TIP2;3 مطالعات نشان داده است كه بيان زن در شرايط عادى بيشتر از تنش شورى است. به طورى كه كاهش معنى دارى در بيان اين زن در ريشه رقم Haruna-Nijo جو تحت تنش شورى ..1

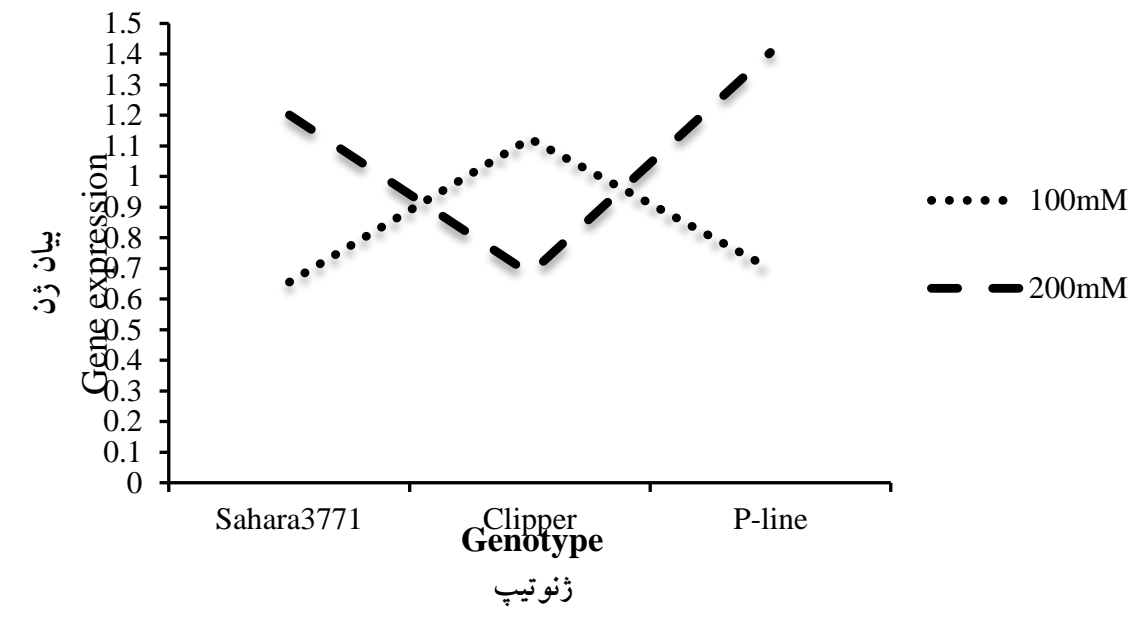

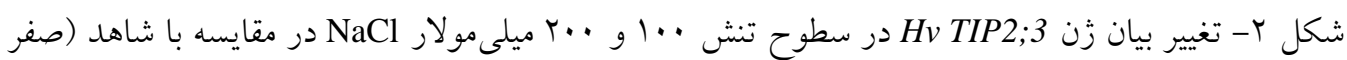
ميلى مولار NaCl) در ارقام جو Clipper، و لاين اميدبخش (P-line) در ميانخين زمانهاى نمونهبردارى

Figure 2. Changes in Hv TIP2; 3 expressions in expose to 100 and $200 \mathrm{mM} \mathrm{NaCl}$ compared to control $(\mathrm{mM} \mathrm{NaCl})$ in Clipper, Sahara3771 and Omid-bakhsh line barley genotypes (P-line) at average samplings stage

$$
\begin{aligned}
& \text { جدول س- تجزيه واريانس بيان زنهاى HV TIP2;3 و HV TIP4;1، در زنوتيبهاى جو تحت سطوح شورى صفر، .'1 و } \\
& \text {. . . ميلى مولار NaCl در زمانهاى نمونه بردارى ب ساعت، سه روز و سه هفته بعد از اعمال تنش }
\end{aligned}
$$

Table 3. Analysis of variance for the expression of $H v$ TIP2;3 and $H v T I P 4 ; 1$ genes in barley genotypes under

\begin{tabular}{|c|c|c|c|c|}
\hline \multicolumn{2}{|c|}{ ميانخين مربعات (MS) } & \multirow{2}{*}{$\begin{array}{c}\text { درجه آزادى } \\
\text { DF }\end{array}$} & \multirow{2}{*}{ SOV } & \multirow{2}{*}{ منابع تغيير } \\
\hline HvTIP4; $1^{\#}$ & $H v T I P 2 ; 3$ & & & \\
\hline $0.238^{\mathrm{ns}}$ & $0.0003^{\mathrm{ns}}$ & 1 & Replication & 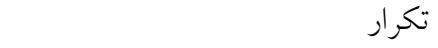 \\
\hline $1.255^{\mathrm{ns}}$ & $0 / 076^{\text {ns }}$ & 2 & Genotype & زَنوتيب \\
\hline $0.149^{\text {ns }}$ & $0.654^{\mathrm{ns}}$ & 2 & Stress & 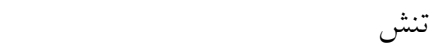 \\
\hline $1.006^{\mathrm{ns}}$ & $1.157^{*}$ & 2 & Genotype $\times$ stress & ز زنوتيّ × تنش \\
\hline 0.573 & 0.137 & 5 & Error 1 & خطاى \\
\hline $0.531^{\mathrm{ns}}$ & $0.163^{\mathrm{ns}}$ & 2 & Sampling time & زمان نمونه بردارى \\
\hline $1.348^{*}$ & $1.106^{* * *}$ & 4 & Genotype $\times$ sampling time & زُنوتيّ × زمان نمونه بردارى \\
\hline $0.406^{\mathrm{ns}}$ & $0.041^{\mathrm{ns}}$ & 2 & Stress $\times$ sampling time & تنش × زمان نمونه بردارى \\
\hline $0.870^{\text {ns }}$ & $0.148^{\mathrm{ns}}$ & 4 & Genotype $\times$ stress $\times$ sampling time & زنوتيٍّ × تنش × زمان نمونه بردارى \\
\hline 0.276 & 0.059 & 12 & Error 2 & خطاى r \\
\hline
\end{tabular}

0,100 and $200 \mathrm{mM} \mathrm{NaCl}$ in 24 h, 3 day and 3 weeks after salt treatment

ns, * and ${ }^{* *}$ : Not significant, significant at $5 \%$ and $1 \%$ probability levels, respectively. 
بر هدايت هيدروليكى (Lp(r)) در ريشه آرابيدوبسيس در

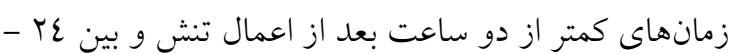

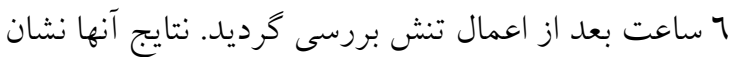
داد كه جلو گيرى از انتقال آب تحت تنش شورى در رابطه بردا با پاسخ سريع گياه است كه اين تغييرات همراه با تغيير در

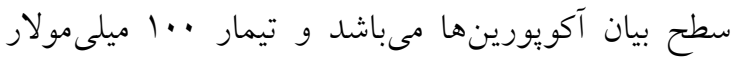
NaCl باعث كاهش •V درصد در Lp(r) شد. در ادامه، سطح بيان زنهاى TIP در ريشه آرابيدوبسيس در شرايط

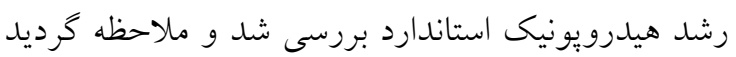
كه زنهاى Hv TIP2;2، Hv TIP1;2 Hv TIP2;3 PIP TIP بيان بالايى در ريشه دارند. بيان زنهاى TIP1;1 در ريشه به جز HIP2;3 و TIP بعد اعمال تنش بايدار بود و در مقابل كاهش قابل ملاحظهاى در رونوشت آكويورينها بين r تا ع ساعت بعد اعمال تنش مشاهده شد. بيشترين كاهش در بيان زن در شش ساعت بعد اعمال تنش با مب درصد براى Hv PIP1;2 و 70 درصد براى HV PIP1;1 و HV TIP2;2 گزارش شد. بيان اكثر اين زنها تا عr ساعت كاهش يافت. به طور كلى

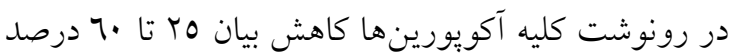
بعد از دو ساعت اعمال تنش شورى مشاهده شد

.(Boursiac et al., 2005)

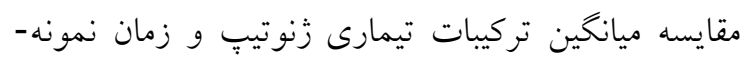
بردارى زن Hv TIP4; در ميانخين سطوح شورى نشان داد

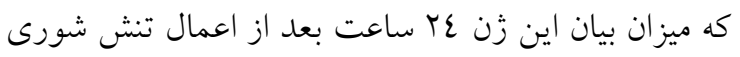

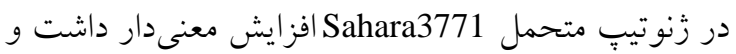
در زنوتيٍ Clipper و لاين اميد بخش افزايش بيان تقريبا مشابهى ديده شد. در سه روز بعد از اعمال تنش شورى، ميزان و روند افزايش بيان زن در هر سه زنوتيٍٍ تقريبا ثابت و نسبت به ع r ساعت بعد از اعمال تنش ميزان بيان كاهش يافت. سه هفته بعد از اعمال تنش ميزان بيان زن در زنوتيِ حساس به شورى Clipper كاهش معنى دار نشان داد و در زنوتيبٍ هاى متحمل مجددا افزايش بيان ديده شد (شكل ع). مشاهده شده است كه بين زنهاى TIP، فراوانى رونوشت زن Hv TIP4;1 در شرايط بدون تنش بالا بوده اما تحت
كزارش شده است كه تنش شورى بالا (200 mM NaCl) به طور معنى دارى هدايت هيدروليكى ريشه جو را كاهش داده و در مقابل تنش شورى ملايم (100 mM NaCl كاهش اندى هدايت هيدروليكى ريشه مىشود ولى تفاوت

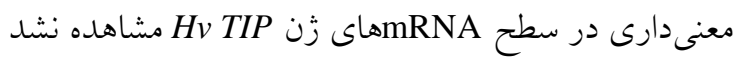

.(Horie et al., 2011) با توجه به معنى دار بودن اثر متقابل دو جانبه زنوتيبٍ ×

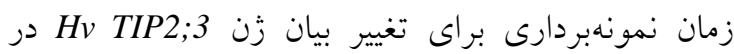

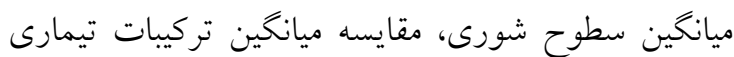

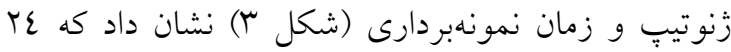

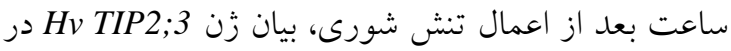
زنوتيبٍ هاى متحمل به شورى Sahara3771 و لاين اميد بخش به طور معنى دار نسبت به زنوتيبٍ حساس به شورى افزايش يافت. اين امر بيان مى كند كه ياسخ اوليه

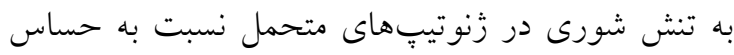
متفاوت است. در سه روز بعد از اعمال تنش شورى، بيان زن HV TIP2;3 در زنوتيبهاى Sahara3771 و لاين اميد بخش كاهش نشان داد كه اين ميزان كاهش در لاين اميد

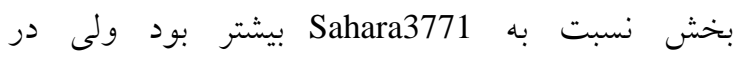
زنوتي״م Clipper (حساس به شورى) افزايش معنىدار در بيان اين زن مشاهده شد. در نهايت در سه هفته بعد از

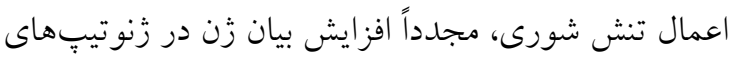

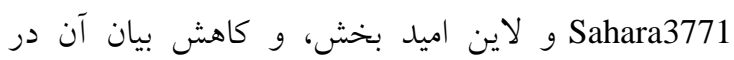

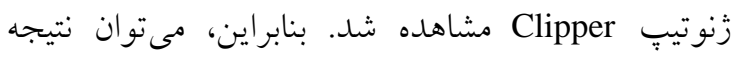

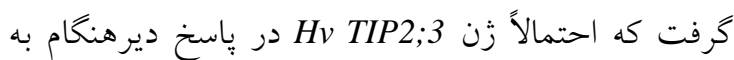
تنش شورى در ارقام متحمل دخالت دارد. زاو و همكاران (Zhu et al., 2005) ذرت، تحت تنش شورى مطالعه كردند و گزارش كردند كه

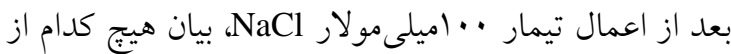
زنهاى Zm TIP تغيير نكرد. در مقابل، بعد از اعمال تيمار

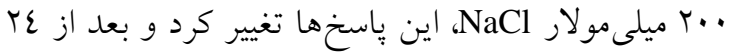

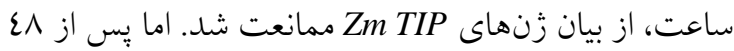
ساعت تغييرات كاهش و يايدارى مشاهده شد. در تحقيقى توسط بورسياى (Boursiac et al., 2005) نيز تأثير شورى 
يزوهشهاى رزنتيك گياهى / جلد Y / شماره r

بيان مىشوند (Sakurai et al., 2005). با بررسى بيان برخى زنهاى HV TIP گزارش شد كه تحت تنش شورى . 1.

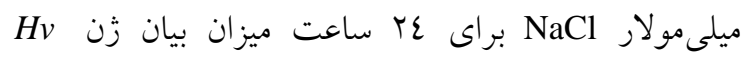
TIP4;1 داد (Ligaba et al., 2011). در يزّوهش ديخرى ثابت كردند كه بين بيان زنها و ياسخ به تنشهاى غيرزيستى از جمله شورى در جو رابطه وجود دارد، به اين صورت كه با بررسى بيان تعدادى از زنها بعد از r، مو rV ساعت بعد از اعمال تنش شورى مشاهده گرديد كه حداكثر تعداد زنهايى كه افزايش بيان داشتند، TV ساعت بعد از اعمال تنش بود. در مقابل، برخى زنها در زمان هشت ساعت كاهش بيان نشان دادند (Waliaet al., 2006). بررسى بيان زنهاى MIP در اندامهاى مختلف آرابيدوبسيس تحت تنش هاى مختلف از جمله شورى با استفاده از RT-PCR نشان داد كه غالبا جندين آكويورين در يك اندام بيان مىشوند و بسيارى از آنها تحت تنشهاى مختلف، كاهش يا افزايش بيان نشان

دادند (Alexandersson et al., 2005).
تنش شورى (FC -15.89) كاهش معنى دارى نشان داد. همين موضوع باعث بيشنهاد وجود نقش حياتى اين زن تحت تنش شورى مىشود (Hove et al., 2015). لى و

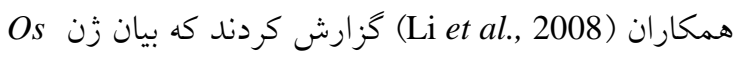
TIP4;1 طورمعنىدار افزايش داشت و ميزان بيان آن در اندامهاى هوايى بيشتر از ريشه بود. با اعمال تيمار شورى •0 اميلى مولار NaCl تغيير فنوتيى در جوانههاى برنج مشاهده نشد ولى بيان زن OsTIP4;1 در ريشه در دو ساعت بعد از اعمال تيمار شورى (مراحل اوليه اعمال تنش) كاهش و سهِ به آرامى افزايش يافت و در هشت ساعت بعد از

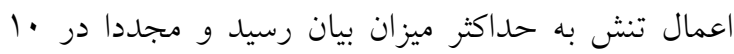
ساعت بعد اعمال تنش كاهش يافت. آنها اظهار داشتند كه احتمالا اين زن در انتقال آب فعاليت دارد. طى آزمايشى سطح بيان زنهاى مختلف از جمله زن Os TIP4;1 در جr و 07 روز بعد از جوانه زنى در ريشه، بيهناى برى و بساك برنج بررسى و مشاهله شد كه اين سه زن در هر سه اندام

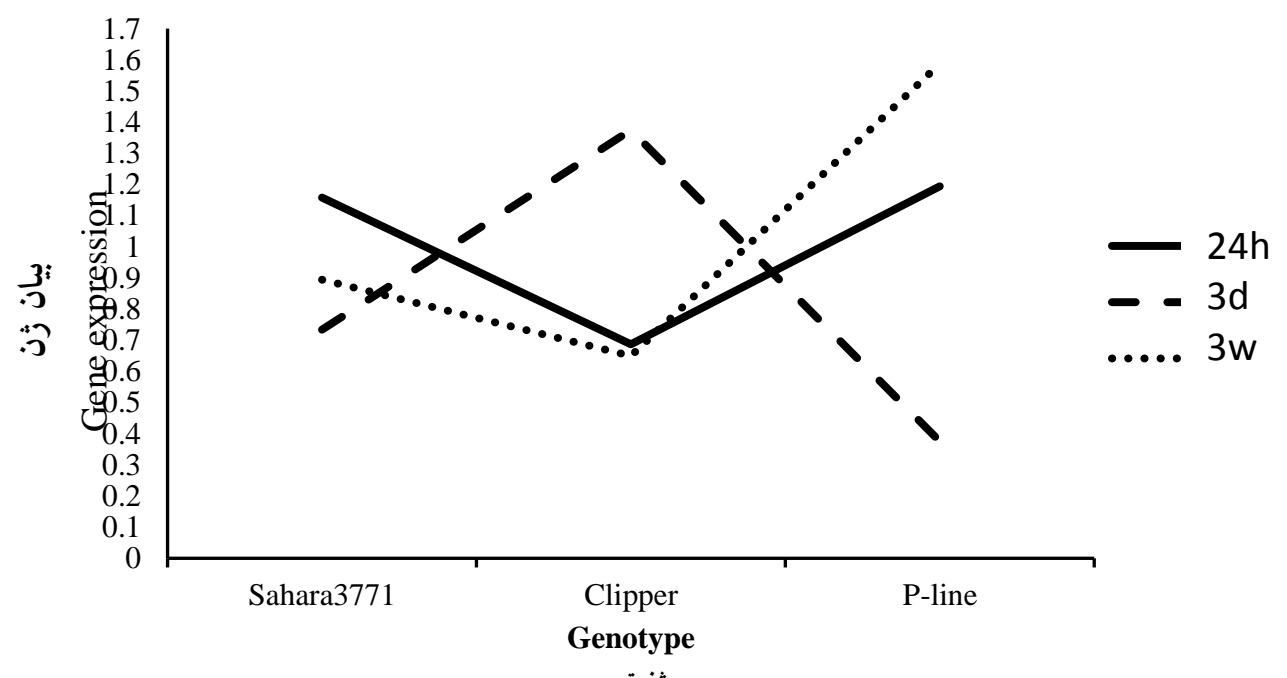

زرنوتيب

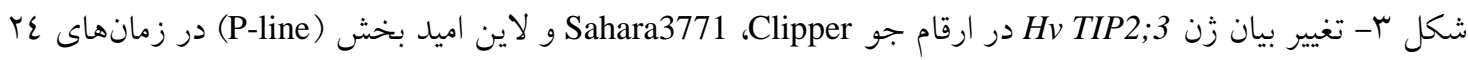

$$
\text { ساعت، سه روز و سه هفته بعد از اعمال تنش در ميانخين سطوح شورى }
$$

Figure 3. Changes in Hv TIP2;3 expression in Clipper, Sahara3771 and Omid-bakhsh line barley genotypes (P-line) at 24 hours, three days and three weeks after applying the average salinity stress levels. 


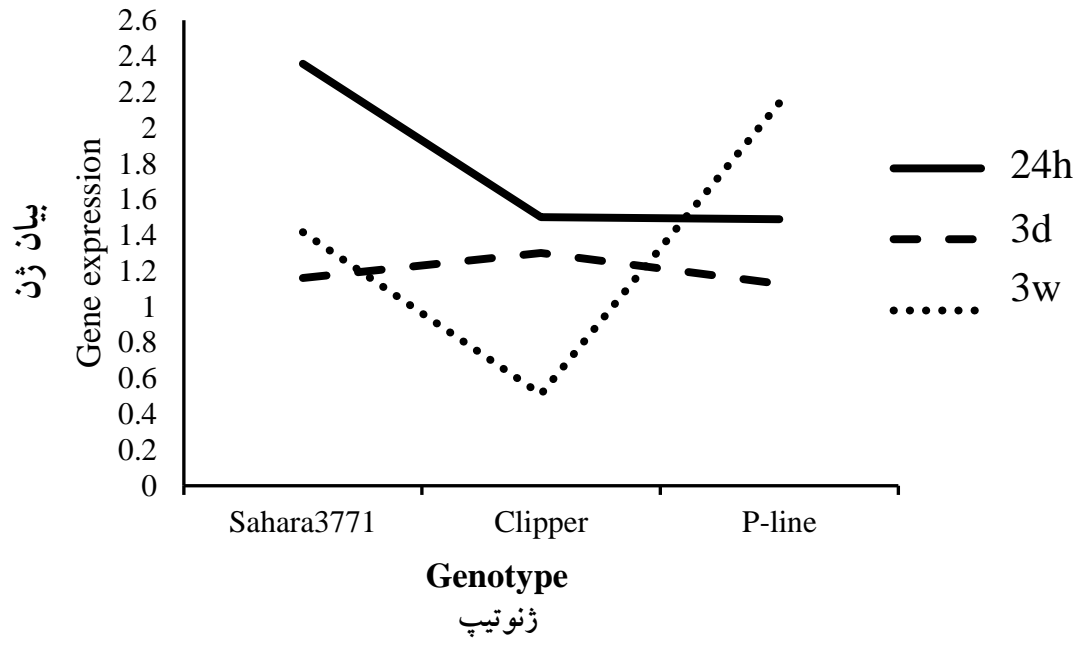

شكل ع- تغيير بيان زن Clipper Sahara3771 و و لاين اميد بخش (PIP4;1 در ارقام جو (P-line در زمانهاى عr

$$
\text { ساعت، سه روز و سه هفته بعد از اعمال تنش در ميانخين سطوح شورى }
$$

Figure 4. Changes in gene expression of Hv TIP4; 1 in barley genotypes of Clipper, Sahara3771 and Omidbakhsh line (P-line) at 24 hours, three days and three weeks after applying the average salinity stress levels

$$
\begin{aligned}
& \text { مولكولى براى بهبود تحمل به شورى را فراهم خو اهد كرد. } \\
& \text { براى مقابله با اثرهاى منفى تنشهاى محيطى، كَاهان از } \\
& \text { طبق نتايج به دست آمده در اين مطالعه نيز مشاهده كرديد بهريد }
\end{aligned}
$$

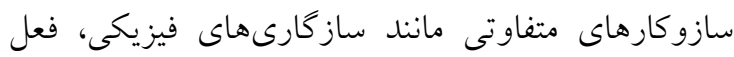

$$
\begin{aligned}
& \text { كه زنهاى HV TIP2;3 و Hv TIP4; }
\end{aligned}
$$

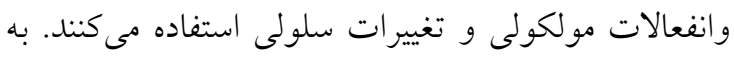

$$
\begin{aligned}
& \text { تنش شورى دجار تغيير بيان شدند. با توجه به نتايج بدست } \\
& \text { دليل بيجيحيده بودن زنتيك تحمل به شورى از بررسى بيان و }
\end{aligned}
$$

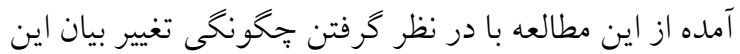

$$
\begin{aligned}
& \text { انتقال زن در كنار ساير روشهاى معمول اصلاحى نيز به به به بـ } \\
& \text { زنها هنگام مو اجهه با شورى در زنوتيٍ مقاوم مى توان در } \\
& \text { عنوان يكى از راهكارهاى افزايش تحمل به شورى در } \\
& \text { بهبود مقاومت به تنش شورى در ارقام حساس به شورى } \\
& \text { كَاهان استفاده مىشود. كزارش شده است كه تنشهاى }
\end{aligned}
$$

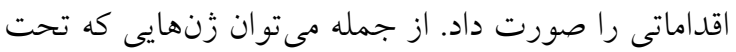

$$
\begin{aligned}
& \text { تنش شورى در زنوتيبهاى مقاوم، افزايش بيان داشتند را رالِ } \\
& \text { با روش هاى مهندسى زنتيك، به كونه هاى حساس به شورى } \\
& \text { كه عملكرد بالا دارند، انتقال داد. } \\
& \text { غيرزيستى از جمله شورى از طريق تغيير در بيان يروتئينها، }
\end{aligned}
$$

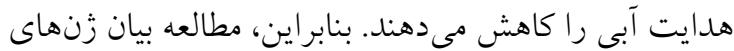

$$
\begin{aligned}
& \text { درگير در تحمل شورى در بافتهاى مختلف گياه، درى } \\
& \text { بهترى از باسخ گياه به تنشهاى غيرزيستى در سطح } \\
& \text { مولكولى ارائه و در نتيجه استفاده مؤثر از روشهاى لتئي }
\end{aligned}
$$

\section{References}

Alexandersson, E., Fraysse, L., Sjovall-Larsen, S., Gustavsson, S., Fellert, M., Karlsson, M., Johanson, U. and Kjellbom, P. (2005). Whole gene family expression and drought stress regulation of aquaporins. Plant Molecular Biology, 59: 469-484.

Besse, M., Knipfer, T., Miller, A., Verdeil, L.J., Jahn, T. and Fricke, W. (2011). Developmental pattern of aquaporin expression in barley (Hordeum vulgare L.) leaves. Journal of Experimental Botany, 62: 4127-4142.

Boursiac, Y., Chen, S., Luu, T.D., Sorieul, M., Van-den Dries, N. and Maurel, C. (2005). Early effects of salinity on water transport in Arabidopsis roots. Molecular and cellular features of aquaporin expression. Plant Physiology, 139: 790-805. 
Ekiz, H. and Yilmaz, A. (2003). Determination of the salt tolerance of some barley genotypes and the characteristics affecting tolerance. Turkish Journal of Agriculture and Forestry, 27: 253-260.

FAOSTAT. (2007). FAO STAT. www.faostat.Fao.org.

FAO .(2013). Biodiversity: Agricultural biodiversity in FAO. www.fao.org/giews/countrybrief/co untry.jsp code IRN.

Forrest, K.L. and Bhave, M. (2008). The PIP and TIPaquaporins in wheat form a large and diverse family with unique gene structures and functionally important features. Functional and Integrative Genomics, 8: 115-33.

Gao, R., Duan, K., Guo, G., Du, Z., Chen, Z., Li, L., He, T., Lu, R. and Huang, J. (2013). Comparative transcriptional profiling of two contrasting barley genotype under salinity stress during the seedling stage. International Journal of Genomics, PMC972852: 1-19.

Glenn, E.P., Brown, J.J. and Khan, M.J. (1997). Mechanisms of salt tolerance in higher plants.In: Basra, A.S. and Basra, R.K. (Eds). Mechanisms of environmental stress resistance in plants. Harwood Academic Publishers, pp. 83-110.

Gimeno, J., Eattock, N., Deynze, A.V. and Blumwald., E. (2014). Selection and Validation of Reference Genes for Gene Expression Analysis in Switchgrass (Panicum virgatum) Using Quantitative Real-Time RT-PCR. PLoS One, 9(3): e91474.

Hassine, A.B., Ghanem, M.E., Bouzid, S. and Lutts, S. (2008). An inland and a coastal population of the Mediterranean xero-halophyte species Atriplex halimus L. differ in their ability to accumulate proline and glycinebetaine in response to salinity and water stress. The Journal of Experimental Botany, 59: 1315-1326.

Horie, T., Kaneko, T., Sugimoto, G., Sasano, S., Panda, S.K., Shibasaka, M. and Katsuhara, M. (2011). Mechanisms of water transport mediated by PIP aquaporins and their regulation via phosphorylation events under salinity stress in barley roots. Plant Cell Physiology, 52: 663-675.

Hove, R.M., Ziemann, M. and Bhave, M. (2015). Identification and Expression Analysis of the Barley (Hordeum vulgare L.) Aquaporin Gene Family. PLoS One,10(6): e0128025.

Jiang, Q., Roche, D., Monaco, T. and Durham, S. (2006). Gas exchange, chlorophyll fluorescence parameters and carbon isotope discrimination of 14 barley genetic lines in response to salinity. Field Crops Research, 96: 269-278.

Knight. H. and Knight, M.R. (2001). Abiotic stress signaling pathways: specificity and cross-talk. Trends in Plant Science, 6: 262-267.

Knipfer, T., Besse, M., Verdeil, J.L. and Fricke, W. (2011). Aquaporin-facilitated water uptake in barley (Hordeum vulgare L.) roots. Journal of Experimental Botany, 62: 4115-4126.

Lefévre, I., Gratia, E. and Lutts, S. (2001). Discrimination between the ionic and osmotic components of salt stress in relation to free polyamine level in rice (Oryza sativa). Plant Science, 161: 943-952.

Li, G., Santoni, V. and Maurel, C. (2014). Plant aquaporins: roles in plant physiology. Biochimica et Biophysica Acta, 1840: 1574-1582.

Li, G.W., Peng, Y.H., Yu, X., Zhang, M.H., Cai, W.M., Sun, W.N. and Su, W.A. (2008). Transport functions and expression analysis of vacuolar membrane aquaporin's in response to various stresses in rice. Journal of Plant Physiology, 165: 1879-1888.

Llanos, A., François, J.M. and Parrou, J.L. (2015). Tracking the best reference genes for RT-qPCR data normalization in filamentous fungi. BMC Genomics, 16: 71-89.

Ligaba, A., Katsuhara, M., Shibasaka, M. and Gemechis, D. (2011). Abiotic stresses modulate expression of major intrinsic proteins in barley (Hordeum vulgare). Comptes Rendus Biologies, 334: 127-139.

Livak, K.J. and Schmittgen, T.D. (2001). Analysis of relative gene expression data using Real-Time Quantitative PCR and the 2- $\Delta \Delta$ ct method. Methods, 25: 402-408. 
Majnoon Hosseini, N. (2004). Cereals Agronomy. University of Tehran Press, Tehran, IR (In Persian). Mosaddek, I., Dai, H., Zheng, W., Gao, F., Zhang, G. and Sun, D. (2013). Genotypic differences in physiological characteristics in the tolerance to drought and salinity combined stress between Tibetan wild and cultivated barley. Plant Physiology and Biochemistry, 63: 49-60.

Pfaffle, M.W. (2001). A new mathematical model for relative quantification in real-time RT-PCR. Nucleic Acids Research, 29: 1-45.

Poustini, K. (2000). Physiological responses of two varieties of wheat to salt stress. Journal of Agricultural Sciences Iran, 2: 124-129.

QIAGEN. (2005). Quantitative ${ }^{\mathrm{TM}}$ SYBR ${ }^{\circledR}$ Green PCR Handbook. Health Research Institute Inc., New York, USA.

Sadder, M.T., Anwar, F. and Al-Doss, A.A. (2013). Gene expression and physiological analysis of Atriplex halimus (L.) under salt stress. Australian Journal of Crop Science, 7:112-118.

Sakurai, J., Ishikawa, F., Yamaguchi, T., Uemura, M. and Maeshima, M. (2005). Identification of 33 rice aquaporin genes and analysis of their expression and function. Plant Cell Physiology, 46: 1568-1577.

Shannon, M.C. (1985). Principles and strategies in breeding for higher salt tolerance. Plant and Soil, 89: $227-241$.

Tyerman, S.D., Niemietz, C.M. and Bramley, H. (2002). Plant aquaporins: multifunctional water and solute channels with expanding roles. Plant, Cell and Environment, 25: 171-173.

Ueda, A., Kanechi, M., Uno, Y. and Inagaki, N. (2003). Photosynthetic limitations of a halophyte sea aster (Aster tripolium L.) under water stress and $\mathrm{NaCl}$ stress. Journal of Plant Research, 116: 65-70.

Ueda, A., Kathiresan, A., Inada, M., Narita, Y., Nakamura, T., Shi, W., Takabe, T. and Bennett, J. (2004). Osmotic stress in barley regulates expression of a different set of genes than salt stress does. Journal of Experimental Botany, 55: 2213-2218.

Vij, S. and Tyagi, A.K. (2007). Emerging trends in the functional genomics of the abiotic stress response in crop plants. Plant Biotechnology Journal, 5: 361-380.

Walia, H., Wilson, C., Wahid, A., Condamine, P., Cui, X. and Close, T.J. (2006). Expression analysis of barley (Hordeum vulgare L.) during salinity stress. Functional and Integrative Genomics, 2: $143-156$.

Wan, H ., Yuan, W., Ruan, M., Ye, Q., Wang, R., Li, Z., Zhou, G., Yao, Z., Zhao, J., Liu, S. and Yang, Y. (2011). Identification of reference genes for reverse transcription quantitative real-time PCR normalization in pepper (Capsicum annuum L.). Biochemical and Biophysical Research Communications, 416: 24-30.

Wang, X., Li, Y., Ji, W., Bai, X., Cai, H., Zhu, D., Sun, X.L., Chen, L.J. and Zhu, Y.M. (2011). A novel Glycine soja tonoplast intrinsic protein gene responds to abiotic stress and depresses salt and dehydration tolerance in transgenic Arabidopsis thaliana. Journal of Plant Physiology, 168: 1241-8.

Widodo, J., Patterson, H., Newbigin, E., Tester, M., Basic, A. and Roessner, U. (2009). Metabolic responses to salt stress of barley (Hordeum vulgare L.) cultivars, Sahara and Clipper, which differ in salinity tolerance. Journal of Experimental Botany, 6: 4089-4103.

Witzel, K., Weidner, A., Surabhi, G.K., Born, A. and Mock, H.P. (2009). Salt stress-induced alterations in the root proteome of barley genotypes with contrasting response towards salinity. Journal of Experimental Botany, 60: 3545-3557.

Yousif, B.S., Nguyen, N.T., Fukuda, Y., Hakata, H., Okamoto, Y., Masaoka, Y. and Saneoka, H. (2010). Effect of salinity on growth, mineral composition, photosynthesis and water relations of two vegetable crops: New Zealand spinach (Tetragonia tetragonioides) and water spinach (Ipomoea aquatica). International Journal of Agriculture and Biology, 12: 211-216. 


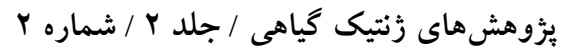

Zaghdoud, C., Mota-Cadenas, C., Carvajal, M., Muries, B., Ferchichi, A. and Martinez-Ballesta. M.C. (2013). Elevated CO2 alleviates negative effects of salinity on broccoli (Brassica oleracea L. var. Italica) plants by modulating water balance through aquaporin's abundance. Environmental and Experimental Botany, 95: 15-24.

Zhao, F.G. andPie, Q. (2005). Protective effects of exogenous fatty acids on root tonoplast function against salt stress in barley seedlings. Environmental and Experimental Botany, 53: 215-223.

Zhu, C., Schraut, D., Hartung, W. and Schaffner, A.R. (2005). Differential responses of maize MIP genes to salt stress and ABA. Journal of Experimental Botany, 56: 2971-2981. 


\title{
Expression Analysis of $H v$ TIP2;3 and Hv TIP4;1 in Sensitive and Tolerant Barley Genotypes Under Salinity Stress
}

\author{
Robab Salamii ${ }^{1, *}$, Seyed Abolghasem Mohammadi², Sara Ghafarian ${ }^{3}$ \\ and Mohammad Moghaddam ${ }^{2}$
}

1- Former M.Sc. Student, Department of Plant Breeding and Biotechnology, Faculty of Agriculture, Tabriz University, Tabriz, Iran

2- Professor, Department of Plant Breeding and Biotechnology, Faculty of Agriculture, Tabriz University, Tabriz, Iran

3- Assistant Professor, Department Biology, Faculty of Science, Shahid Madani Azarbijan University, Tabriz, Iran

(Received: January 15, 2016 - Accepted: March 07, 2016)

\begin{abstract}
Barley is the most salt tolerant cereal, and is grown in a wide range of climatic conditions. To improve the plant tolerance to salinity, expression analysis of genes involved in stress tolerance could be effective in identification and development of tolerant genotypes. In this study, for evaluation of salinity effect on expression of $H v$ TIP2;3 and Hv TIP4; 1 genes (encoding channel proteins in the membrane) in roots of barley, three genotypes; Clipper (salt susceptible), Sahara3771 (salt tolerant) and advanced breeding line (a salt tolerant line derived from a cross between Kavir and Sahra cultivars) were planted under 0, 100 and $200 \mathrm{mM} \mathrm{NaCl}$. To determine the expression differences of these genes, RNA was extracted from root samples harvested at 24 hours, 3 days and 3 weeks after applying salinity treatments and cDNA was generated. Analysis of variance revealed a significant difference among genotypes, salinity levels and sampling stages for $H v T I P 2 ; 3$ and $H v$ TIP4; 1 genes expression pattern, whereas genotype $\times$ salinity interaction for $H v$ TIP2;3and genotype $\times$ sampling stage interaction were significant for both of the studied genes. The expression of TIP 2;3 gene in the $100 \mathrm{mM} \mathrm{NaCl}$ was increased in salt susceptible genotype Clipper and decreased in tolerant genotypes compared with control. Mean comparison of genotype and sampling combination showed that the expression level of $H v T I P 4 ; 1$ gene at 3 weeks after salinity stress was increased in Sahara and advanced breeding line and decreased in Clipper. According to the results, it was confirmed that these genes are affected by salinity stress, and effective utilization of this genes in the barley in order to increase salinity tolerance could lead to desirable results.
\end{abstract}

Keywords: Aquaporins, Expression pattern, Tonoplast intrinsic proteins, Barley, $H v T I P 2 ; 3$ and $H v$ TIP4; 1 genes

\footnotetext{
* Corresponding Author, E-mail: r.salami1990@gmail.com
} 